\title{
Film Tourism In Norway: The Effect Fictional Characters Have On Tourism
}

\author{
Brian Metcalf, University of Cincinnati, USA \\ Cathrine Linnes, Østfold University College, Norway \\ Jerome Agrusa, University of North Texas, USA \\ Joseph Lema, Stockton University, USA
}

\begin{abstract}
The impact Walt Disney's animated film Frozen is having on Disney's bottom line and on tourism within Norway is highlighted. Although Frozen takes place in fictional Arendelle, movie producers incorporated Norwegian inspired scenery, imagery, and culture. Using a bi-lingual survey (English and Norwegian), we analyzed how the movie has increased travel in Norway, who appears to be most influenced to consider Norway as a travel destination, compared attitudes of film audiences in the U.S., Norway, and other countries on a variety of related factors, and provide suggestions concerning marketing connections to the movie Frozen in an attempt to further boost tourism within Norway.
\end{abstract}

Keywords: Movie Tourism; Film Tourism; Tourism Impact; Place Identity; Disney; Frozen

\section{INTRODUCTION}

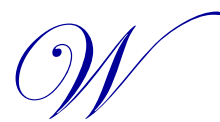
alt Disney's movie Frozen is the company's juggernaut animated blockbuster, released in November 2013 (Del Vecho, Buck, \& Lee, 2013). The movie and accompanying merchandise is making Disney some serious cold cash as customers demonstrate they are certainly willing to "Let It Go." Within just months of being released, this movie became the top grossing animated movie of all time (McClintock, 2014), the top grossing film of 2013, and the fifth top-grossing movie in the world of all time (Box Office Mojo for Frozen, 2014). In just over one year's time, the film grossed over $\$ 1.3$ billion worldwide at the box office alone. Nominated for two Academy Awards, "Let It Go" won both "Best Animated Feature" and "Best Original Song" in February 2014. The franchise money making potential for Frozen also seems to be limitless. Bob Iger, Chairman and Chief Executive Officer of Disney, noted that Frozen "has real franchise potential" and stated that, "we will be seeing Frozen in more places than we've seen so far," (The Walt Disney Company, 2014, p. 13).

And, we have certainly seen the Frozen franchise in many places already! Disney recently announced that a sequel for Frozen is in the works (Graser, 2015). Characters from the movie were inserted into the storyline of the $4^{\text {th }}$ season of ABC's popular Once Upon a Time series. A Frozen on Ice tour was developed and immediately became Disney's most popular ice show of all time, selling 250,000 tickets on its first day and leading company to project total sales reaching three million (Murray, 2014). Disney Stores everywhere and theme parks were initially unable to adequately meet the demand for related merchandise. Frustrated parents took to social media to complain about not being able to buy Frozen merchandise demanded by their children. Nine of the ten best-selling items at Disney Store in the second quarter of 2014 were Frozen-related (Fritz, 2014). By the end of April 2014, Disney Parks had to impose a five-item limit at its stores, while many other Disney Store outlets had imposed a two-item limit on Frozen retail items and resorted to requiring customers to enter into a lottery on busiest days just for the chance to purchase the very popular Frozen character costumes (Thurston, 2014; Zakarin, 2014). The phenomenon calls to mind the classic "Cabbage Patch Kids" and "Tickle Me Elmo" crazes of yesteryear, but on steroids. Just in time for the 2014 year-end holidays, Frozen toppled "Barbie" from her more than a decade-long throne as the number one demanded toy for girls (Kell, 2014a). Sales of Frozen toys and other merchandise were projected to hit $\$ 1$ billion in the United States alone in 2014, nearly matching its worldwide box office draw so far, giving Disney, as well as toy manufacturers Mattel and Jakks Pacific a boost when overall retail sales for the key 2014 holiday season appeared choppy. Furthermore, WalMart had more than 700 Frozen items, Toys ' $R$ ' Us had more than 300, and eBay reports over 40,000 listings for 
Frozen gear on its website (Kell, 2014b). Frozen ended 2014 as the year's most popular DVD or Blu-Ray, nearly tripling the sales of runner-up The Hunger Games: Catching Fire and the Frozen soundtrack, selling nearly 3.5 million copies, beat Beyoncé, Taylor Swift and One Direction to top the Billboard charts for 2014 (Murray, 2014).

One of the recent featured attractions at the various Disney Parks (e.g., Disneyworld, Disneyland, Epcot Centre, etc.) have been daily meet-and-greet opportunities for children with actors portraying the main characters from Frozen. These have been overwhelmingly popular with typical wait times of 3-5 hours and sometimes reaching as long as six hours (Epcot's Frozen Meet and Greet, 2014; Lush, 2014). Paint and other décor to match the look of Frozen have been applied throughout the Norway Pavilion within the World Showcase of Epcot Centre in Florida. For example, the entryway sign to one of the Pavilion buildings is in Frozen colors and reads "Norsk Kultur: Inspiration for Disney Frozen" (as pictured in Munarriz, 2014). Disney has greatly increased the percentage of gift shop space devoted to Frozen-themed merchandise and the character Meet-and-Greets (Munarriz, 2014). For months, there were rumors that Disney had plans to replace or refurbish the theme ride "Maelstrom" within the Pavilion, a Viking boat ride through scenes inspired by Norwegian imagery and culture, with a Frozen-themed ride of some sort. In September 2014, Disney officially reported that the ride was indeed closing in October 2014 with the following announcement: "The new attraction, which replaces Maelstrom, will take our guests to Arendelle and immerse them in many of their favorite moments and music from the film. The pavilion will also include a royal greeting location where Anna and Elsa can meet our guests" (Staggs, 2014, para. 2).

All of this is helping the Walt Disney Corporation to make profits sure to have Scrooge McDuck quacking with glee. Astonishing profits of $\$ 12.47$ billion in the third quarter of 2014 alone led Disney to exceed everyone's predictions (Nakashima, 2014). Subsequent quarters followed this trend with Disney seeing revenues of $\$ 12.39$ billion and $\$ 13.39$ billion, respectively (The Walt Disney Company, 2015). In addition to the wildly successful release of motion pictures from elsewhere in their catalog such as the Marvel series (e.g., Iron Man, The Avengers, Thor, Captain America, and Defenders of the Galaxy) and other animated features, and the inevitable success the upcoming Star Wars entries will bring now that this franchise is part of Disney, the company seems poised to continue earning dizzying profits. But, the interest in Frozen and the demand for its related merchandise seems to have taken even ultra-marketing and merchandise savvy Disney by surprise.

\section{BACKGROUND}

\section{Frozen and Norway Tourism}

An unanticipated area of lucrative increase that seems to be related to the move Frozen has been to the tourism industry of Norway. While Frozen is loosely based on the Danish Hans Christian Andersen fairytale, The Snow Queen, the movie takes place in the mythical land, Arendelle, which the movie producers largely based upon Norwegian locations, imagery, and cultural references. The movie's art director, Michael Giaimo, travelled to Norway in 2011 and gained much of his inspiration from the city of Bergen and Norway's west coast (Zara, 2014). Arendelle was inspired by Nærøyfjord, a portion of Norway's longest fjord Sognefjorden. Several landmarks in Norway appear, including the Akershus Fortress in Oslo, the Nidaros Cathedral in Trondheim, and the Bryggen wharf area in Bergen. Many other Norwegian cultural elements such as Vikings, trolls, stave churches, clothing including the traditional "bunad" costumes, and foods such as lutefisk are featured in the film (Del Vecho et al. 2013). This very conscious and deliberate effort to incorporate Norwegian themes together with the phenomenal success of the film has led to a significant, though perhaps unpredicted uptick in travel and tourism within the country. Frozen features a playful song called, "Do You Want to Build a Snowman?" Child and parent fans alike seem intent on seeing the inspiration for their beloved Arendelle and building one there!

Traffic to the website VisitNorway.com tripled after the film's release and visits to a page linked from their front page with a Frozen banner garnered 10 times the number of hits of other key pages on the site. Travel on the low-cost airline Norwegian Air Shuttle ASA has increased by 52\%. Flight Tracker reported that searches for Norwegian flights rose by 153\%, while hotel bookings went up 37\% (Harpaz \& Rising, 2014; Zara, 2014). According to Visit Norway, tour operators like Wilderness Travel reported increases of 20-40\% in sales to Norway for the 2014 season and arrivals from New York at the Oslo Airport for the first quarter of 2014 were up 57\% over the same period the year prior to the release of the film (Baran, 2014). The luxury travel agent network Virtuoso reported a $65 \%$ increase in bookings 
to Norway (Mitchell, 2014). "It put Norway on the map," says Beate Gran, digital media manager and marketing coordinator for the government's Innovation Norway website (Zara, 2014, para. 3). While the increases might be surprising for some, they were not entirely unanticipated by Disney's guided tours division. "Adventures by Disney" approached Innovation Norway about a partnership half a year before the film's release in 2013. While few predicted the actual phenomenon that Frozen would become, Hege Barnes, the director of the New York branch of Innovation Norway, says her organization did not need to wait for box-office numbers before jumping at the chance to align with the Mighty Mouse. "We saw the opportunity right away," she says. "Norway is a tiny little destination, relatively unknown in the US, so for us to be tied to a world-renowned brand such as Disney was huge" (Zara, 2014, para. 4).

Disney itself began advertising new cruise options to Norway, encouraging travelers to "experience all the beauty and majesty our tour of Norway has to offer as you explore the quaint villages and stunning landscapes that served as the inspiration for Disney's Frozen. You and your family will follow in the filmmaker's footsteps as you hike, raft and traverse the awe-inspiring terrain" ("Norway Adventures by Disney," 2014, para. 1). The maiden cruises, not beginning until mid-2015, were already almost sold out in July, 2014 (Mitchell, 2014).

\section{Film-Induced Tourism}

Previous studies (e.g., Cho \& Agrusa, 2007: Desai \& Basuroy, 2005) have examined the influence of media such as film and TV on the marketing of a destination as well as with various audience characteristics (Kwak, Zinkhan, \& Dominick, 2002). The connection between film and tourism to locations depicted in them is well documented (Dore \& Crouch, 2003; Kim, Chen, \& Su, 2009; Riley, Baker, \& Van Doren, 1998; Riley \& Van Doren, 1992). According to Morgan and Pritchard (1998), placing a destination in a film is the ultimate in tourism product placement known as Destination Product Placement. A large number of studies have identified diverse aspects of film tourism, including the motivation of film tourists (e.g., Beeton, 2005; 2010; Macionis, 2004; Macionis \& Sparks, 2009; Riley \& Van Doren, 1992) or the perception of a destination's image by film tourists (e.g., Butler, 1990; Chalip, Green, \& Hill, 2003; Croy, 2010; Frost, 2006; O’Connor, Flanagan, \& Gilbert, 2010; Sealy \& Wickens, 2008). Past studies have described the impacts of film/television tourism (e.g., Aitchison, Macleod, \& Shaw, 2000; Croy, 2011; Han \& Lee, 2008; Heitmann 2010; Kim, Agrusa, Chon, \& Cho, 2008; Kim, Agrusa, Lee, \& Chon, 2007; Riley \& Van Doren, 1992; Riley et al. 1998; Tooke \& Baker, 1996), while film-induced tourism literature has also analyzed the cultural perspectives of film tourism (e.g., Bandyopadhyay, 2008; Huang, 2011; Su, Huang, Brodowsky, \& Kim, 2011). Hudson and Ritchie (2006) compiled results from 33 popular films and TV programs listing the destination(s) depicted in them and noting the impact on visitor numbers to those locations or tourist revenue generated, including such massive increases as 300\% more visitors to Wallace Monument in Scotland the year after it was depicted in the movie Braveheart and a 200\% increase in visitors to national parks in Sydney in 2000 after the release of Mission: Impossible 2. Indeed, most studies consistently demonstrate that film/television are mediums that attract tourists to a film destination or film story-related destinations (Kim, Agrusa, \& Chon, 2014). The present research manuscript summarizes the first systematic and scientific study of film-induced tourism affecting Norway that we are aware of, and therefore, the first of Disney's Frozen movie.

\section{METHODOLOGY}

To investigate the research questions pertaining to the perceived impact that the Disney movie Frozen is having on audience members' desire to travel to/within Norway, over 1,000 surveys in the U.S. and Norway with both English and Norwegian versions were collected from participants from all over the world. The survey instrument asked questions about the film, the respondents' and their family members' desire to travel to/within Norway to experience the sights and culture represented by the movie, as well as other questions and demographics.

This study explores 1) how the intense popularity of the movie has increased travel to/within Norway and awareness of Norway as a travel destination; 2) who is being influenced most by the movie to consider Norway as a travel destination and what their audience characteristics are; 3 ) the similarities and differences between the film's audiences in the U.S. and in Norway in terms of desire to travel to/within Norway, and 4) whether Norway and Norwegian tourism officials should increase marketing and connections to the movie Frozen in an attempt to further boost tourism to/within that country. Several specific hypotheses were: 
Hypothesis 1: Overall, respondents who have seen the movie Frozen will indicate a higher degree of interest in traveling within Norway to see the actual sights that inspired the depictions in the movie "Frozen" than those who did not see the movie.

Hypothesis 2: Respondents from outside of Norway will indicate a higher degree of interest than Norwegian respondents in traveling within Norway.

Hypothesis 3: Respondents who have children and have seen the movie Frozen will indicate a higher degree of interest in travelling within Norway to see the actual sights that inspired the depictions in the move "Frozen" than respondents who have not seen the movie and do not have children.

Hypothesis 4: The higher respondents rank their enjoyment of the movie Frozen, the higher their interest in seeing the actual sights that inspired the depictions in the movie and the higher their approval of how Norwegian culture is portrayed in the movie will be.

Hypothesis 5: As the movie features female lead characters and is more popular with females, female respondents who have seen the movie Frozen will indicate the highest level of desire to travel within Norway to see the actual sights that inspired the depictions in the movie.

Multi-item scales were used to measure most of the constructs that served as the basis for the questionnaire items. The item scales were modified in part from previous studies (e.g., Ajzen \& Fishbein, 1980; Bearden \& Teel, 1980; Chen \& Wells, 1999; Davis, 1989; Davis, Bagozzi, \& Warshaw, 1989; Schubert \& Selz, 1999; Succi \& Walter, 1999; Zhou, 2002) to serve the objectives of the present study. Likert scales were used to measure many of the items with a fivepoint scale used with extremes labeled "Strongly Disagree" and "Strongly Agree." The survey questionnaire was originally written in English and then translated into Norwegian. According to (McGorry, 2000) when translating a survey instrument into another language the use of the double translation method (back translation) is paramount when utilized prior to distribution (McGorry, 2000). The double translation method is one of the most adequate translation processes even though occasions exist where the literal translation process may have missing information, (Lau \& McKercher, 2004).

This study was distributed via Facebook and a variety of websites in the US and Norway, in both English and Norwegian languages. Responses were received from 1,071 total participants. Each version consisted of a consent statement followed by 21 closed-format questions, with multiple opportunities for respondents to share open-ended thoughts and opinions. All surveys were completely voluntary with no overt incentives or compensation offered to participants.

\section{RESULTS}

The mean age of the respondents was $32.2(\mathrm{SE}=.44)$ years old, the median was 29 , and ages ranged from $18-90$ years old. The mean age and range for respondents from the U.S., Norway, and Other Countries (all others combined) were similar to these and to each other. The mean age of respondents who saw the movie was $31.6(\mathrm{SE}=.47)$ and the mean age of those who did not see it was 34.1 ( $\mathrm{SE}=1.12$ ). Fifty-five percent of respondents were from the U.S. and $39 \%$ were from Norway. The $6 \%(\mathrm{~N}=55)$ respondents from outside of the U.S. or Norway (Other Countries) represent 16 countries with Saudi Arabia (15) and Canada (11) being the largest two (with the remaining countries having five or fewer respondents). Figure 1 depicts the country of residency of participants who completed the demographics portion of the survey. Forty-one states (and DC) in the U.S. were represented in the sample, with Hawaii, Florida, California, Pennsylvania, and New York being the five states with the most participants, respectively. Overall, more females $(61 \%)$ than males $(39 \%)$ responded to the survey. 
Figure 1. The percentage and number of respondents from the U.S., Norway, and Other Countries.

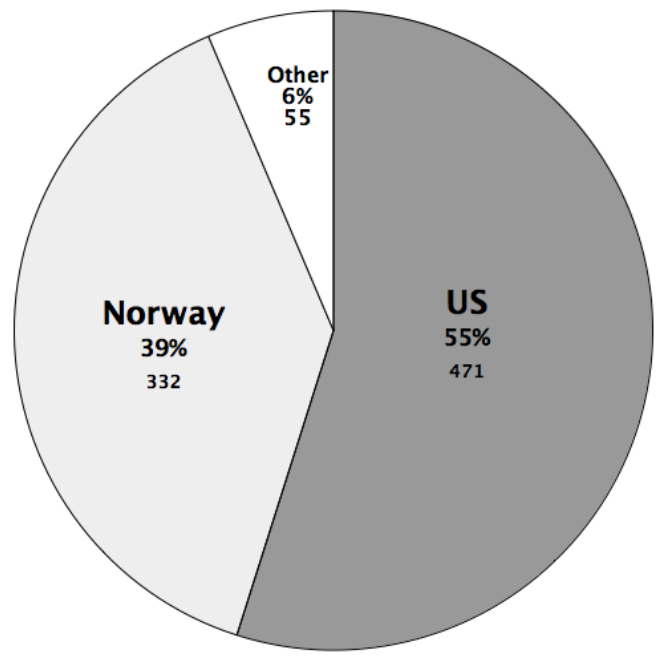

Figure 2 depicts the relative number and percentage of the gender of the respondents by which language of the survey they completed (English or Norwegian). Among those taking the English version of the survey, 44\% and 32\% ( = $100 \%$ )of the total participants in the study were females and males, respectively, and among those responding on the Norwegian version, $17 \%$ and $7 \%$ were females and males, respectively.

Figure 2. The percentage and number of the total respondents by gender and language of survey.

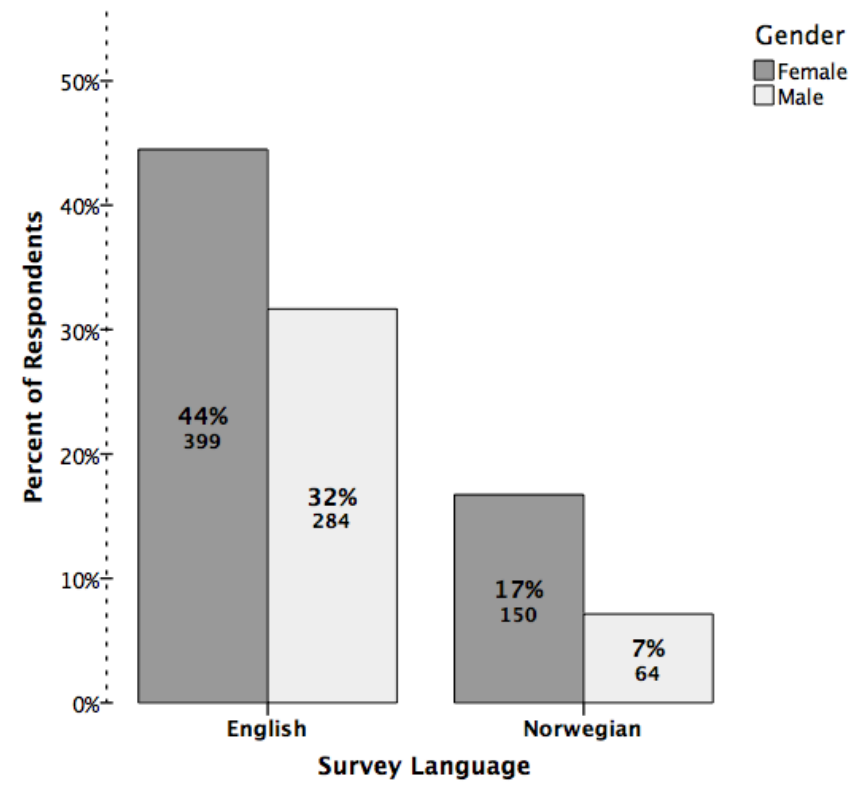

Overall, 79\% of the participants reported having seen the movie Frozen. Being an American movie, perhaps it isn't surprising that a significantly higher percentage of respondents from the U.S. reported seeing Frozen (85.5\%) than Norwegians $(68.2 \%)$ and those from Other Countries $(67.3 \%), \chi^{2}(2)=35.29, \mathrm{p}<.001$ with a Cramér's $V=.21$. While $21 \%$ of the overall respondents reported that they hadn't seen the movie, approximately half (49\%) of the respondents reported having seen it more than once, and about as many people (20\%) as those who hadn't seen the movie reported 
seeing it five or more times. Consistent with the success and popularity of the movie, $73 \%$ rated the movie favorably on a scale of $1-10$ as a five or higher.

\section{Hypothesis 1}

One of the primary questions and points of interest concerned whether respondents had a desire to travel within Norway to see the actual sights that inspired depictions in the movie Frozen. Overall, respondents reported a mean Disagree (1) to Strongly Agree (5), indicating a general agreement to this statement. However, as seen in Figure 3, and as we hypothesized, respondents of 3.42 out $5(\mathrm{SE}=.04)$ on this Likert scale question ranging from Strongly who saw the movie indicated a stronger desire with a mean of $3.47(\mathrm{SD}=.04)$ than those who did not see the movie $(\mathrm{M}=$ $3.19, \mathrm{SD}=.09$ ). An Independent-samples t-test revealed this to be a significant difference, $\mathrm{t}(856)=2.90, \mathrm{p}=.004$, although with a small estimated effect size of $\mathrm{r}=.10$.

Comparing the expected versus the actual numbers for the various categories of the combination of respondents who did or did not see the movie and those who indicated a desire or not to see the sights that inspired the depictions in the movie Frozen. All other things being equal (which they probably aren't since Norway does have a reputation for natural beauty), if seeing the movie truly had no bearing on or relationship with peoples' desire or not to see the sights, then one could expect roughly equal percentages within the cells of each of the answer options to the question "do you have a desire to see the sights" (yes, no, and unsure) and "have you seen the movie" (yes or no). However, great deviation from this expected result exists. For example, if seeing the movie truly had no bearing on this attitude, one would expect to see equal percentages of people who saw the movie to say "yes" and "no" to this question. Yet, fully $87.8 \%$ of the participants who said "yes" to this desire were people who saw the movie. And rather than equal thirds responding "yes," "no," and "unsure" to this desire, nearly half (49.1\% rather than $33 \%$ ) of those stating "yes" were people who had seen the movie. A Chi Square analysis found these proportions to be significantly different than chance, $\chi^{2}(2)=37.84, p<.001$ with a Cramér's $V=.21$.

Figure 3. Mean levels of agreement to the question, "I would be interested in traveling within Norway to see the actual sights that inspired the depictions in the movie Frozen by those who reported to have, and have not, seen the movie.

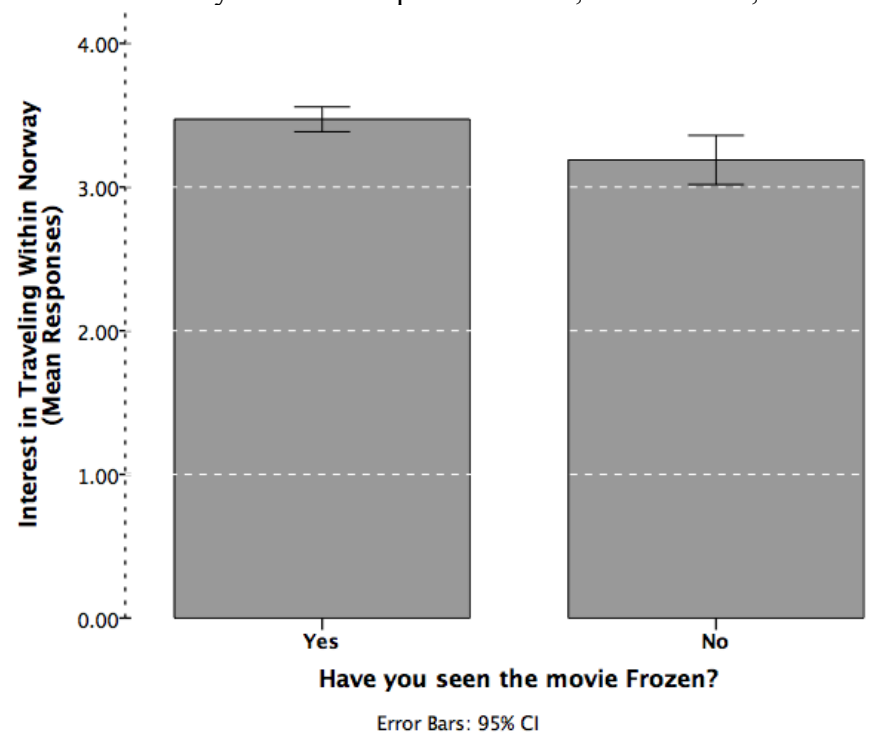

\section{Hypothesis 2}

The second hypothesis, that respondents from outside of Norway will indicate a higher degree of interest than Norwegian respondents in traveling within Norway to see the actual sights that inspired the depictions in the move "Frozen" received support from our results. Approximately $51 \%$ of respondents from the U.S. and $53 \%$ of respondents 
from Other Countries responded affirmatively to this question while $34 \%$ from Norway did. A Chi Square analysis found these proportions to be significantly different than chance, $\chi^{2}(4)=22.43, p<.001$ with a Cramér's $V=.12$.

Similarly, as can be seen in Figure 4, respondents from the U.S. and from Other Countries had means (and SD) of $3.52(.05)$ and 3.38 (.16), respectively, on the Likert scale question "I would be interested in traveling within Norway to see the sights that inspired depictions in the movie" while the mean for Norwegians was 3.30 (.07). A One-Way Between-Groups ANOVA confirmed these differences to be significant, $F(2,797)=3.21, p=.041$, but with an estimated effect size of just $\eta^{2}=.01$. A planned comparison of the means between Norway and all other countries was found to be not significant, $\mathrm{t}(797)=1.41, \mathrm{p}=.16$, perhaps due to the inclusion of a far smaller sample size from Other Countries, but the comparison between Norway and the U.S. was significant, $\mathrm{t}(797)=2.51, \mathrm{p}=.011$.

Figure 4. The mean levels of agreement to the question, "I would be interested in traveling within Norway to see the actual sights that inspired the depictions in the movie Frozen, by country of residence reported by participants.

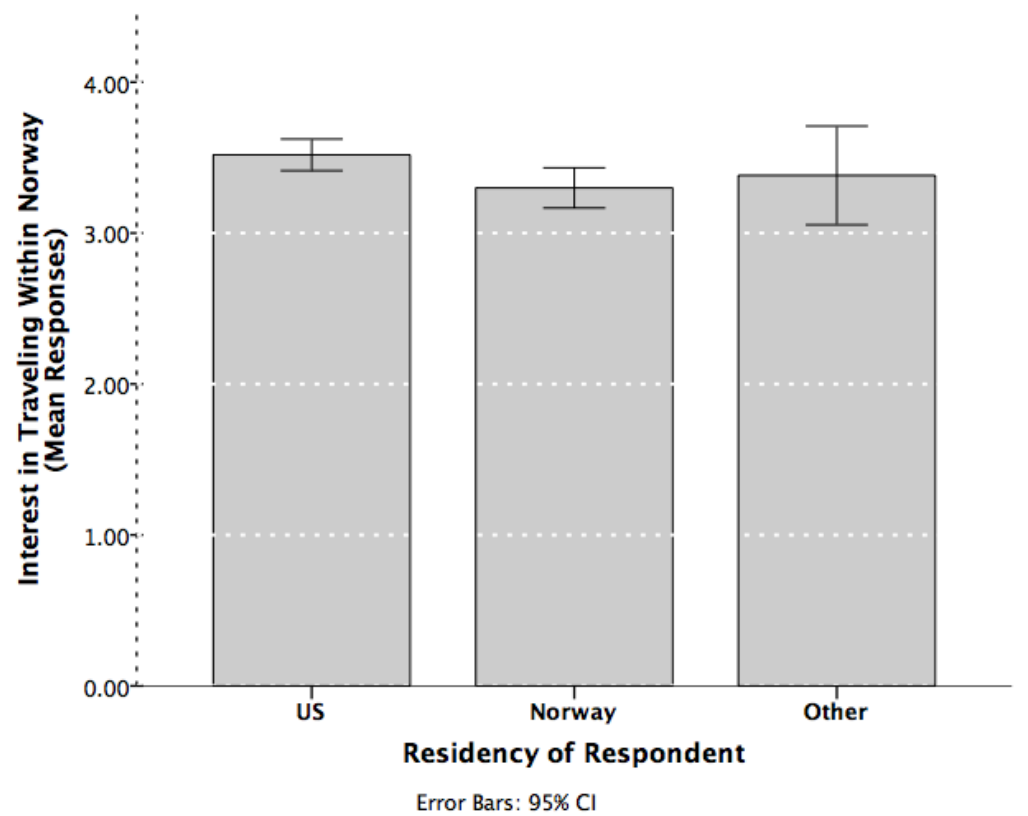

A third way to quantify this interest in traveling within Norway to see these sights is by combining "Agree" and "Strongly Agree" responses to the question "I would be interested in traveling within Norway to see the actual sights that inspired the depictions in the movie." Doing so produces a slightly different pattern of results in that $61 \%$ of U.S., $56 \%$ of Other Countries, and $44 \%$ of Norwegian respondents indicate agreement to this statement. Respondents from the U.S. and from Other Countries had means (and SD) of 2.41 (.04) and 2.31 (.12), respectively, on this Likert scale question while the mean for Norwegians was 2.25 (.05). A One-Way Between-Groups ANOVA confirmed these differences to be significant, $F(2,797)=3.78, p=.023$, but with an estimated effect size of just $\eta^{2}=.01$. A significant Levine's statistic $(\mathrm{p}=.02)$ warned of a possible violation of homogeneity of variances, but this was discounted as likely due to the relatively large sample sizes from the U.S. and Norway and the small sample size from Other Countries and because Welch and Brown-Forsythe results were in the same direction as the uncorrected ANOVA. A planned comparison of the means between Norway and all other countries was found to be not significant, $t(797)=$ $1.50, \mathrm{p}=.14$, perhaps due to the inclusion of a far smaller sample size from Other Countries, but the comparison between Norway's lower mean and the U.S. was significant, $t(797)=2.72, \mathrm{p}=.007$.

While it might not be surprising that people from the US (61\%) and other countries (56\%) were more interested in traveling within Norway than Norwegians were in order to see the sights that inspired depictions in the movie, it is interesting that up to $44 \%$ of Norwegians indicated this desire to travel within their country to see them as well. 


\section{Hypothesis 3}

The hypothesis that respondents who have children and have seen the movie Frozen will indicate a higher degree of interest in travelling within Norway to see the actual sights that inspired the depictions in the move "Frozen" than respondents who have not seen the movie and do not have children was not specifically supported by the data. But, an interesting result emerged from this analysis. Firstly, the mean level of interest in traveling within Norway for respondents who have children $(\mathrm{M}=3.46, \mathrm{SE}=.07)$ was not significantly different than the mean for those who do not have children $(\mathrm{M}=3.40, \mathrm{SE}=.05), \mathrm{t}(858)=.79, \mathrm{p}=.43$. Figure 5 displays the mean interest in traveling within Norway for males and females, with and without children, who have and have not seen Frozen. The prediction was that those who have children and have seen the movie (presumably with their child/children) would express a higher level of interest in traveling within Norway than people without children and who have not seen the movie (who were expected to show the least interest by not being inspired by either the movie or by children who have). The Two-Way Between-Groups ANOVA for this original analysis revealed results consistent with the previously reported significant difference between those who have seen the movie and those who have not, and a non-significant difference between those with and without children, but no significant interaction between having children or not seeing the movie.

Figure 5. The mean levels of agreement to the question, "I would be interested in traveling within Norway to see the actual sights that inspired the depictions in the movie Frozen, for males and females, with and without children, and who have and have not seen the film.

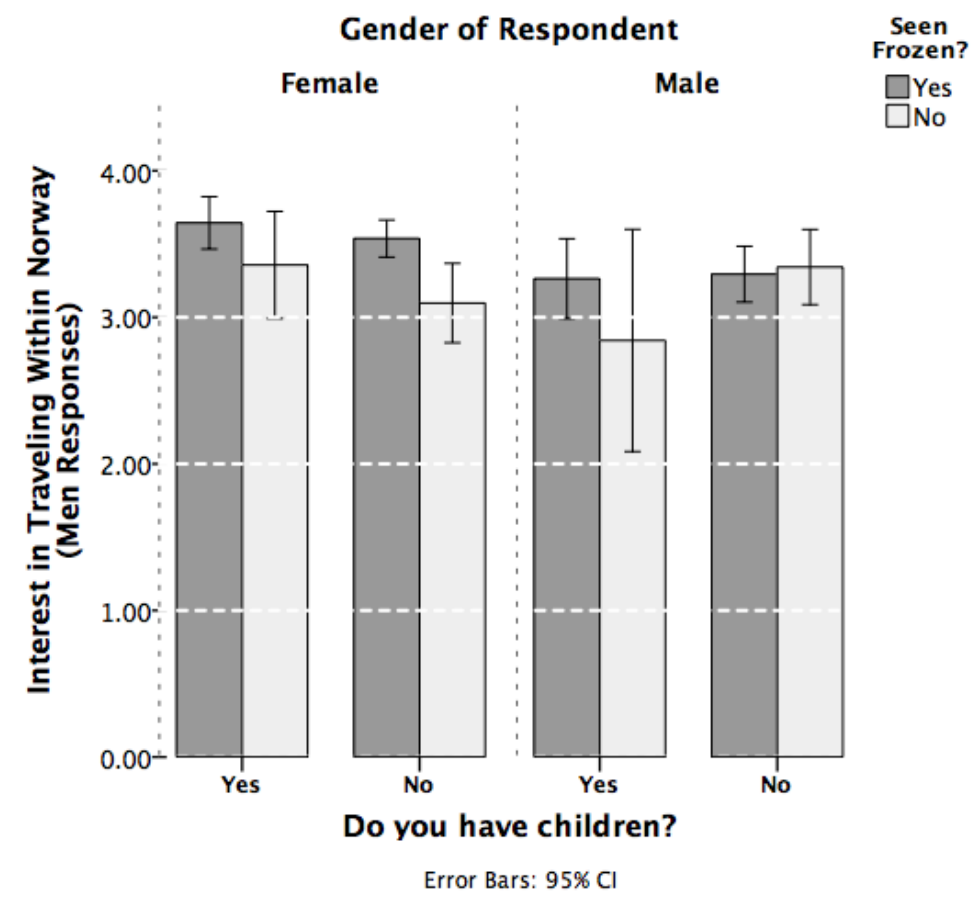

Adding Gender to this analysis produced an interesting result. In line with the result that females who have seen the movie expressed significantly greater interest in traveling within Norway than the other three categories, the researchers expected that adding the factor of having children or not might result in the mean for females, who have seen the movie and have children (i.e., mothers who have seen the movie) being the highest. The results demonstrated that females with children had the highest interest in traveling within Norway. One surprising result was that fathers who did not see the movie [whether their child(ren) have seen it or not] had the lowest mean interest in traveling within Norway of any other category that we explored. The interaction component analysis this potential difference is contained within was not significant, $\mathrm{F}(1,849)=1.63, \mathrm{p}=.20$, but it is conceivable to us that this is due to the rather wide variability displayed within this small sample category (just 19 men). 


\section{Hypothesis 4}

The fourth hypothesis, that the higher respondents rank their enjoyment of the movie Frozen (on a scale of 1-10), the higher will be (1) their interest in traveling to Norway to see the actual sights that inspired the depictions in the movie and (2) their approval of how Norwegian culture is portrayed in the movie, were both supported by the data. The mean rank of the movie given by the respondents was $6.16(\mathrm{~S}=.90)$ on a scale of $1-10$ and the mean level of agreement of all respondents on the 5-item Likert scale statement, "I would be interested in traveling within Norway to see the actual sights that inspired the depictions in the movie Frozen" was $3.42(\mathrm{~S}=.86)$ with a Pearson's $\mathrm{r}=.29, \mathrm{p}<.001$. However, when factoring out the approximately $20 \%$ of respondents who did not see the movie and consequently gave it a low ranking (most gave it a 0 , meaning "I did not see the movie"), the correlation was much stronger at $\mathrm{r}=$ $.43, \mathrm{p}<.001$. The mean level of agreement of all respondents on the 5-item Likert scale statement, "I approve of how Norwegian culture is portrayed in the movie Frozen" was $3.30(\mathrm{~S}=.86)$. This correlated with the respondents' rank of the movie with a Pearson's $r=.30, p<.001$. Likewise, as seen in Figure 6 , when factoring out all of the respondents who did not see the movie, the correlation rose to $\mathrm{r}=.45, \mathrm{p}<.001$.

Figure 6. A significant positive correlation exists $(r=.45)$ between the participants' rating of the movie "Frozen" on a scale of 110 and how strongly they agree with the statement, "I approve of how Norwegian culture is portrayed in the move," among those who have seen the film. No correlation exists between the two variables for those who had not seen the movie.

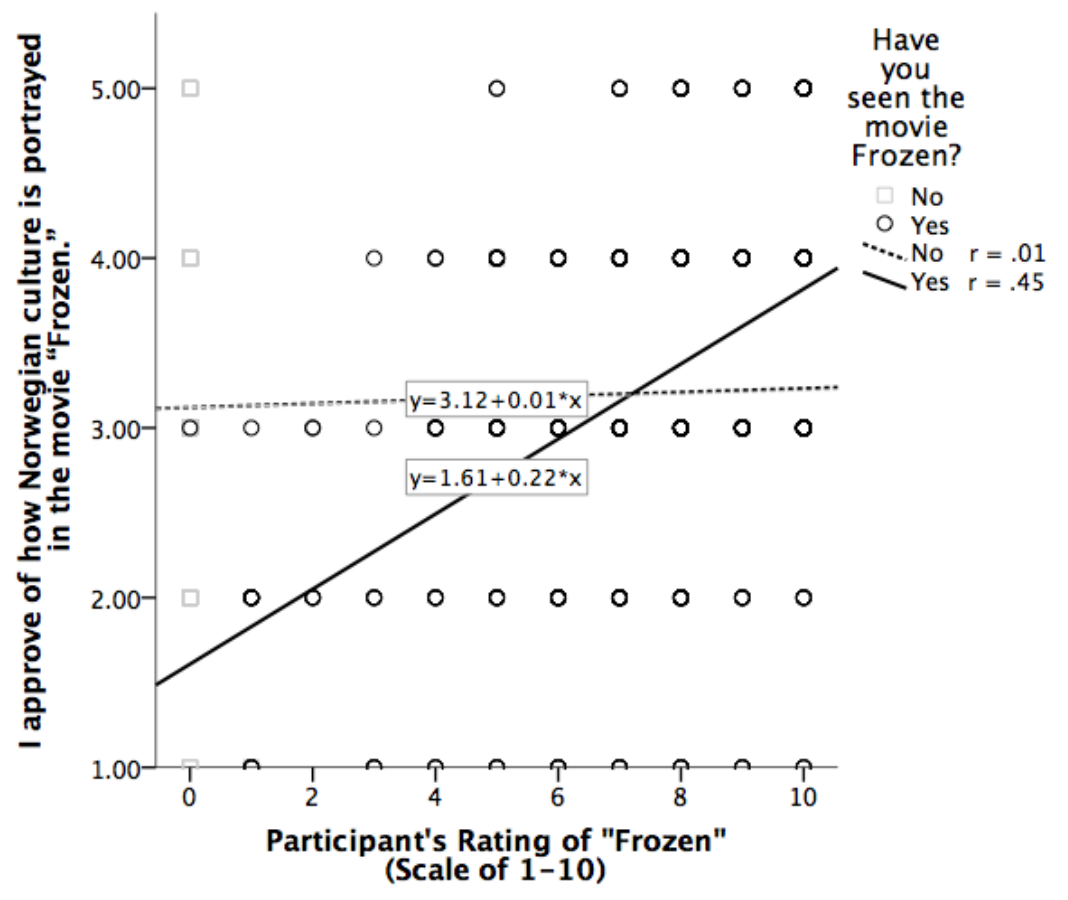

\section{Hypothesis 5}

The $5^{\text {th }}$ hypothesis is that given the higher degree of popularity of the movie Frozen among females that it would be females who have seen the movie who would indicate a higher level of desire than males to travel within Norway to see the actual sights that inspired the depictions in the movie. The results suggest this is true. As can be seen in Figure 7, between males and females who either have or have not seen the movie, females had the highest mean level of agreement to this question $(\mathrm{M}=3.57, \mathrm{SE}=.05)$, while the mean (and $\mathrm{SE})$ for females who have not seen the movie was 3.14 (.12) and the means for males who have and have not seen the movie were 3.29 (.07) and 3.24 (.12), respectively, were all similarly lower. 
Figure 7. The mean levels of agreement among female and male participants who have and have not seen the movie "Frozen," to the statement "I would be interested in traveling within Norway to see the actual sights that inspired the depictions in the movie Frozen."

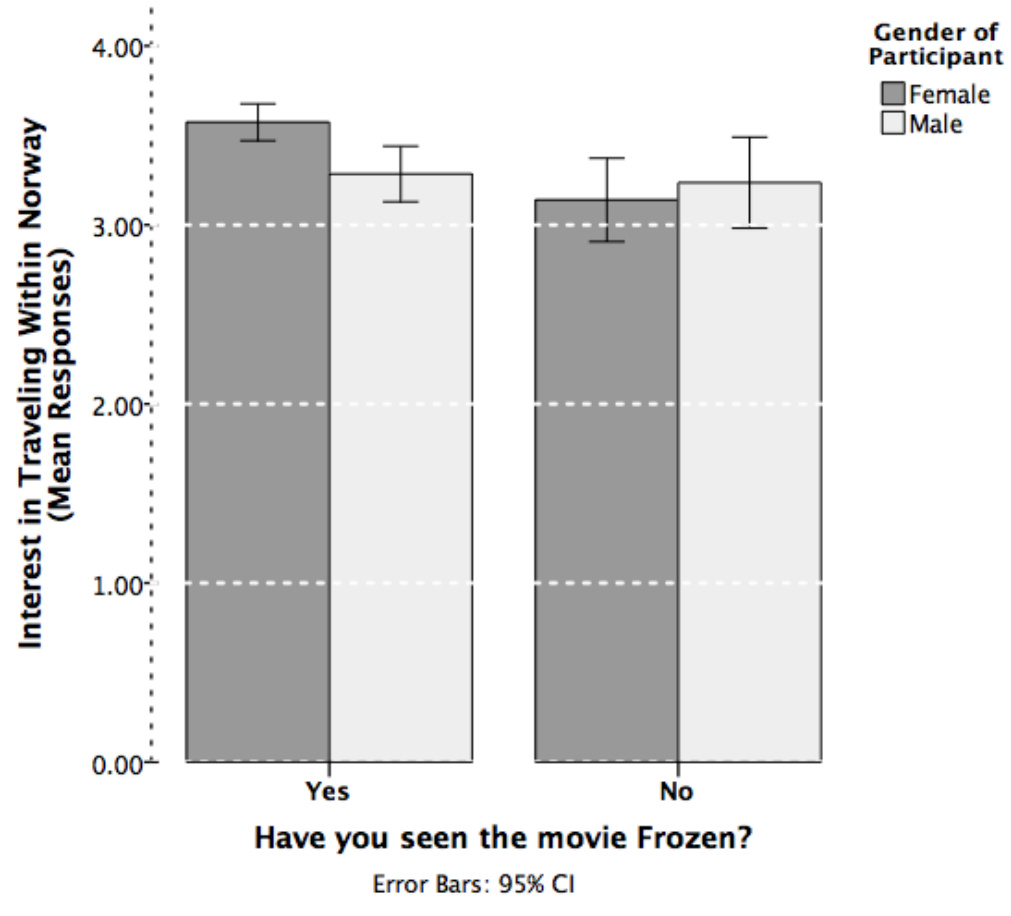

A Two-Way Between-Subjects ANOVA revealed a significant main effect for having seen the movie or not, $\mathrm{F}(1,853)$ $=6.05, \mathrm{p}=.014$, partial $\eta^{2}=.007$, no significant main effect for gender, $\mathrm{F}(1,853)=.96, \mathrm{p}=.33$, partial $\eta^{2}=.001$, and a significant interaction of gender by having seen the movie, $F(1,853)=3.86, p=.05$, partial $\eta^{2}=.005$. All of these partial $\eta^{2}$ values of effect size are on the small side. To localize this significant interaction, a simple effects analysis confirmed that there were no significant differences between the means for males who both did and did not see the movie and females who did not see the movie $\mathrm{F}(1,853)=.31, \mathrm{p}=.58$, but that the mean for females who did see the movie was significantly higher than males who have seen the movie, $F(1,853)=9.87, p=.002$. Perhaps Disney and/or Norway might specifically wish to target efforts at female viewers of Frozen in efforts to boost tourism within Norway. Conversely, perhaps efforts and investments would be better spent if aimed at the other targets to boost their desire to travel in Norway.

\section{CONCLUSION}

The primary hypothesis here was that viewers of Frozen would be inspired by that movie to travel to Norway to see the sights and culture depicted or represented in that movie, particularly if they were aware of its connection to the scenery and culture of Norway. While we are not able to isolate and control factors as in an experimental context in order to determine causality, our primary method of addressing this hypothesis was to ask participants "Do you desire to see the sights in Norway depicted in Frozen?" (with the answer options yes, no, unsure), and then to state their level of agreement on the 5-point Likert scale statement, "I would be interested in traveling within Norway to see the actual sights that inspired the depictions in the movie Frozen." As reported above, there were significant differences on these items between those who saw the movie and those who didn't. For the Likert scale version of this question, this significant difference was accompanied by a rather small effect size estimate $(r=.10)$. It is conceivable that while this is a significant difference, the mean difference and therefore the estimate of the effect size may be tempered by the fact that such a survey overtly suggests to participants the idea that seeing the movie may influence one to see the sights depicted, and that this might inspire some disagreement with this notion in the participant's mind. A large number of the respondents indicated in the comments for this question that the movie (or movies in general) did not (or could not) influence their desire to travel within Norway and/or that they had this desire before seeing or hearing 
about the movie. In other words, people widely discount the notion that a movie, especially an animated one, could or would affect such opinions or behavior.

A great deal of evidence from research on film-induced behavior and attitudes, including the present study, reveals just the opposite; media depictions do most certainly have the ability to shape viewers and to have measurable effects on tourism. Furthermore, a preponderance of research evidence from psychology also demonstrates conclusively that people's attitudes, beliefs, decisions, and other behaviors are very frequently shaped by multitudes of factors they are unaware of and/or that they deny have any effect on them (Gilbert, 2007; Martin, Goldstein, \& Cialdini, 2014). Evidence also shows that Product Placement (PPL) is frequently used in films and television. A new trend that has only recently been examined is that of Destination Placement (DPL) which has been used in films and television, to promote or introduce a destination to the viewing audience. Results of this research on the movie Frozen suggest that DPL of Norway within this animated film may have evoked audiences to be aware of a certain brand destinations (Norway) which ultimately affects the purchase decision process when buying a holiday package tour or vacation travel to a destination.

In sum, this study has in common with previous studies the idea that a movie can be a medium to attract tourists to a filming, actor-related, or original work-related locations. The popularity of backdrop destinations shown in visual programs is similar to the phenomenon of artistic and literary places as tourist attractions (Busby \& Klug, 2001; Herbert, 1996; Newby, 1981; Seaton \& Hay, 1998; Square, 1994). Furthermore, as indicated earlier, marketing filming destinations is an ultimate form of product placement (DPL) closely linked to the concepts of destination branding because the featured locations can be considered to be a product with brand loyalty, brand image and brand equity (Cai, 2002; Gnoth, 1998; Kim \& Agrusa, 2005; Williams \& Palmer, 1999). A film that portrays a prime DPL can also inspire people to visit the location for years afterwards. According to Beeton (2010), there is ample anecdotal evidence that tourists look for film sites and even reenact fantasies portrayed in movies at those film locations. It is, perhaps, too early to know if Disney's Frozen will have legs to stand the test of time in terms of the influence it will have on the minds and imaginations of viewers - and therefore the potential DPL influence on tourism within Norway - but, Disney has an excellent track record with other similar animated features and there seems to be a timeless quality about the Frozen that may serve well in this regard.

For now, there is evidence that the successful animated film, Frozen, has enticed tourists to visit a country that has had limited tourism previously. With plans to create a sequel to Frozen officially announced by Disney in March 2015 (Messer, 2015) and no end in sight yet to the popularity of and demand for Frozen-themed merchandise, it is probably safe to predict that Norway will continue to experience an increase in interest and actual tourism for years to come. This Disney Frozen franchise seems to be leading many to answer, "Yes!" to the question, "Do you want to build a snowman in Norway?"

\section{AUTHOR BIOGRAPHIES}

Brian Metcalf, Ph.D. is an Assistant Professor - Educator in the Department of Psychology at the University of Cincinnati. He is also on the consultant team along with Dr. Philip Zimbardo for "Aetas Mind Developing Apps" (www.discoveraetas.com). His research focus is in Zimbardo Time Perspective Theory and Therapy, understanding and promoting Heroism and helping behavior, and consumer behavior. He received his Ph.D. from the University in Georgia.

Cathrine Linnes, Ph.D. is an Associate Professor in Computer Science at Østfold University College where she serves as a faculty member in the undergraduate and graduate programs. She is also serving on the executive council for Upsilon Pi Epsilon. Her research focus is in software development, network analysis and use of technology and analytics to solve business problems. She received her Ph.D. from Nova Southeastern University and has several years of work experience in the travel and tourism industry.

Jerome Agrusa, Ph.D. is a Professor and Chair of the Hospitality \& Tourism Management program at University of North Texas. He is a Fulbright Senior Specialist and he serves on numerous editorial review boards. He is also serving on the board of the Asia Pacific Tourism Association. His research focus is in sports, destination and movie tourism. He received his Ph.D. from Texas A\&M University 
Joseph Lema, Ph.D., a resident of Philadelphia, Pennsylvania, USA, is a Professor of Hospitality and Tourism Management in the School of Business at Stockton University located outside Atlantic City, New Jersey. His professional experience includes managing throughout the hospitality industry in ultra-competitive markets. He is a Fulbright scholar through the US State Department as well as a US-ASEAN Fulbright Specialist who lectures and conducts research in the area of hospitality \& tourism services and higher education. Professor Lema serves on numerous editorial review boards along with memberships in hospitality and tourism industry associations.

\section{REFERENCES}

Aitchison, C., Macleod, N. E., \& Shaw, S. J. (2000). Leisure and tourism landscapes: Social and cultural geographies. London: Routledge.

Ajzen, I. \& Fishbein, M. (1980). Understanding attitudes and predicting social behavior. Englewood Cliffs, NJ, Prentice-Hall.

Bandyopadhyay, R. (2008). Nostalgia, identity and tourism: Bollywood in the Indian diaspora. Journal of Tourism and Cultural Change, 6(2), 79-100. doi:10.1080/14766820802140463

Baran, M. (2014, July 7). Disney's 'Frozen' is sending tourists packing for Norway, operators report. Travel Weekly, 73(27), 150 .

Bearden, W. O. \& Teel, J. E. (1980). An investigation of personal influences on consumer complaining. Journal of Retailing, 56(3), 3-20.

Beeton, S. (2005). Film-induced tourism: Aspects of tourism. Clevedon, England: Channel View Publications.

Beeton, S. (2010). The advance of film tourism. Tourism and Hospitality Planning \& Development, 7(1), 1-6. doi: $10.1080 / 14790530903522572$

Box Office Mojo for Frozen (2014). Retrieved August 3, 2014, from http://boxofficemojo.com/movies/?id=frozen2013.htm.

Busby, G., \& Klug, J. (2001). Movie-induced tourism: The challenge of measurement and other issues. Journal of Vacation Marketing, 7(4), 316-332.

Butler, R. W. (1990). The Influence of the media in shaping international tourism patterns. Tourism Recreation Research, 15(2), 46-55.

Cai, L. (2002). Cooperative branding for rural destinations. Annals of Tourism Research, 29, 720-742.

Chalip, L., Green, C., \& Hill, B. (2003). Effects of sport event media on destination image and intention to visit. Journal of Sports Management, 17, 214-234.

Chen, Q. \& Wells, W. D. (1999.) Attitudes toward the site. Journal of Advertising Research, 27-37.

Cho, Y. \& Agrusa, J. (2007). How the media is a significant promotional tool to deliver marketing messages to audiences? International Business \& Economics Research Journal, 6(10), 61-74.

Croy, W. G. (2010). Planning for film tourism: Active destination image management. Tourism and Hospitality Planning \& Development, 7(1), 21-30. doi:10.1080/14790530903522598

Croy, W. G. (2011). Film tourism: Sustained economic contributions to destinations. Worldwide Hospitality and Tourism Themes, 3(2), 159-164. doi:10.1108/17554211111123014

Davis, F. D. (1989). Perceived usefulness, perceived ease of use, and user acceptance of information technology. MIS Quarterly, 13(3), 319-340.

Davis, F. D., Bagozzi, R. P., \& Warshaw, P. R. (1989). User acceptance of computer technology: A comparison of two theoretical models. Management Science, 35(8), 982-1003.

Del Vecho, P. (Producer), Buck, C., \& Lee, J. (Directors) (2013). Frozen [Motion picture]. United States: Walt Disney Animation Studios.

Desai, K. K. \& Basuroy, S. (2005). Interactive influence of genre familiarity, star power, and critics' reviews in the cultural goods industry: The case of motion pictures. Psychology and Marketing, 22(3), 203-223.

Dore, L., \& Crouch, G. I. (2003). Promoting destinations: An exploratory study of publicity programmers used by national tourist organizations. Journal of Vacation Marketing, 9, 137-51.

Epcot's Frozen Meet and Greet to offer extended hours. (2014, February 7). Retrieved August 4, 2014, from http://www.wdwmagic.com/attractions/norway/news/07feb2014-epcot's-frozen-meet-and-greet-to-offer-extendedhours.htm.

Fritz, B. (2014, May). Disney's film business gets big boost from 'Frozen.' Wall Street Journal. Retrieved August 3, 2014, from http://online.wsj.com/news/articles/SB10001424052702304101504579546090651005438.

Frost, W. (2006). Braveheart-ed Ned Kelly: Historic films, heritage tourism and destination image. Tourism Management, 27, 247-254. doi:10.1016/j.tourman.2004.09.006

Gilbert, D. T. (2007). Stumbling on happiness. New York: Vintage Books.

Gnoth, J. (1998). Conference reports: Branding tourism destinations. Annals of Tourism Research, 25, 758-760.

Graser, M. (2015, March). Disney announces 'Frozen 2.' Retrieved July 26, 2015, from http://variety.com/2015/film/news/disney-announces-frozen-2-1201451480/.

Han, H., \& Lee, J. (2008). A study on the KBS TV drama Winter Sonata and its impact on Korea's Hallyu tourism development. Journal of Travel \& Tourism Marketing, 24(2-3), 115-126. doi:10.1080/10548400802092593 
Harpaz, B. J., \& Rising, M. (2014, June). Disney 'Frozen' frenzy includes Norway tourism. Retrieved August 3, 2014, from http://bigstory.ap.org/article/disney-frozen-frenzy-includes-norway-tourism

Heitmann, S. (2010). Film tourism planning and development - questioning the role of stakeholders and sustainability. Tourism and Hospitality Planning \& Development, 7(1), 31-46. doi:10.1080/14790530903522606

Herbert, D. (1996). Artistic and literary places in France as tourism attractions. Tourism Management, 17, 77-85.

Huang, S. (2011). Nation-branding and transnational consumption: Japan-mania and the Korean wave in Taiwan. Media, Culture \& Society, 33(1), 3-18.

Hudson, S., \& Ritchie, J.R.B. (2006). Promoting destinations via film tourism: An empirical identification of supporting marketing initiatives. Journal of Travel Research, 44(4), 387-396. Doi: 10.1177/0047287506286720

Kell, J. (2014a, November). 'Frozen' dethrones Barbie as top toy for girls this holiday. Retrieved January 1, 2015 from, http://fortune.com/2014/11/25/frozen-dethrones-barbie/.

Kell, J. (2014b, December). Why Disney's 'Frozen' is the hottest toy of the year. Retrieved January 1, 2015 from, http://fortune.com/2014/12/23/frozen-is-the-toy-of-the-year/.

Kim, H. J., Chen, M. H., \& Su, H. J. (2009). The impact of Korean TV dramas on Taiwanese tourism demand for Korea. Tourism Economics, 15, 867-73.

Kim, S. S., Agrusa, J., \& Chon, K. (2014). The influence of a TV drama on visitors' perception: A cross-cultural study. Journal of Travel \& Tourism Marketing, 31(4), 536-562. doi: 10.1080/10548408.2014.883950doi:10.1177/0163443710379670

Kim, S. S., Agrusa, J., Chon, K., \& Cho, Y. (2008). The effects of Korean pop culture on Hong Kong residents' perceptions of Korea as a potential tourist destination. Journal of Travel \& Tourism Marketing, 24, $2-3$. doi: 10.1080/10548400802092684

Kim, S. S., Agrusa, J., Lee, H., \& Chon, K. (2007). Effects of Korean television dramas on the flow of Japanese tourists. Tourism Management, 28(5), 1340-1353. doi:10.1016/j.tourman.2007.01.005

Kim, S., \& Agrusa, J. (2005). The positioning of overseas honeymoon destinations. Annals of Tourism Research, 32(4), 887-904.

Kwak, H., Zinkhan, G. M., \& Dominick, J. R. (2002). The moderating role of gender and compulsive buying tendencies in the cultivation effects of TV shows and TV advertising: A cross-cultural study between the U.S. and South Korea. Media Psychology, 4(1), 77-111.

Lau, A. L. S. \& McKercher, B. (2004). Exploration versus acquisition: A comparison of first-time and repeat visitors. Journal of Travel Research, 42, 279-285.

Lush, T. (2014, June 5). Families in a frenzy over Disney's 'Frozen`. Retrieved March 6, 2018, from https://www.seattletimes.com/nation-world/families-are-in-a-frenzy-over-disneyrsquos-lsquofrozenrsquo/

Macionis, N. (2004). Published in: W. Frost, G. Croy, \& S. Beeton (Eds.), International Tourism Media Conference Proceedings (pp. 86-97): Understanding the film-induced tourist. In Berwick: Monash University Tourism Research Unit.

Macionis, N., \& Sparks, B. (2009). Film-induced tourism: An incidental experience. Tourism Review International, 13, 93-101. doi: $10.3727 / 154427209789604598$

Martin, S. J., Goldstein, N., \& Cialdini, R. (2014). The small BIG: small changes that spark big influence. New York: Grand Central Publishing

McClintock, P. (2014, March). Box office milestone: 'Frozen' becomes No. 1 animated film of all time. Retrieved August 3 , 2014, from http://www.hollywoodreporter.com/news/box-office-milestone-frozen-becomes-692156

McGorry, S. (2000). Measurement in a cross-cultural environment: Survey translation issues. Qualitative Market Research, 3(2), 74.

Messer, L. (2015, March). 'Frozen 2' is in development, Disney announces. Retrieved April 5, 2015, from http://abcnews.go.com/Entertainment/frozen-development-disney-announces/story?id=29590120.

Mitchell, H. (2014, June). Frozen tours to Norway take off as film tourism reaches a fever pitch. Retrieved August 3, 2014, from https://www.yahoo.com/travel/film-tourism-and-the-frozen-phenomenon-frozens-90553256692.html

Morgan, N., \& Pritchard, A. (1998). Tourism promotion and power: Creating images, creating identities. Chichester, UK: John Wiley \& Sons.

Munarriz, R.A. (2014, July). Norway is giving Disney the cold shoulder over 'Frozen'. Retrieved August 3, 2014, from http://www.dailyfinance.com/2014/07/24/frozen-norway-disney-epcot.

Murray, N. (2014, December). Ice Age 2014: Remembering the year 'Frozen' took over. Retrieved January 1, 2015 from, http://www.rollingstone.com/music/features/the-year-in-frozen-20141231\#ixzz3NZg3miW1.

Nakashima, R. (2014, August 5). 'Frozen' helps Disney 3Q profit rise 22\%. Retrieved August 5, 2014, from http://abcnews.go.com/Business/wireStory/disney-3q-profit-rises-22-percent-24854931.

Newby, P. (1981). Literature and the fashioning of tourist taste. In D. Pocock (Ed.), Humanistic Geography and Literature: Essays on the Experience of Place (pp. 130-141). London: Croom Helm.

Norway Adventures by Disney (2014). Retrieved August 3, 2014, from http://www.adventuresbydisney.com/europe/norwayvacation.

O’Connor, N., Flanagan, S., \& Gilbert, D. (2010). The use of film in re-imaging a tourism destination: A case study of Yorkshire, UK. Journal of Vacation Marketing, 16(1),61-74. doi:10.1177/1356766709356611

Riley, R. W, \& Van Doren, C. S. (1992). Movies as tourism promotion: A 'pull' factor in a 'push' location. Tourism Management, 13, 267-75. doi:10.1016/0261-5177(92)90098-R 
Riley, R., Baker, D., \& Van Doren, C. S. (1998). Movie induced tourism. Annals of Tourism Research, 25, 919-35. doi:10.1016/S0160-7383(98)00045-0

Schubert, P. \& Selz, D. (1999). Published in the proceedings of the $32^{\text {nd }}$ Hawaii International Conference on System Sciences: Web assessment: Measuring the effectiveness of electronic commerce sites going beyond traditional marketing paradigms.

Sealy, W. \& Wickens, E. (2008). Published in the proceedings of the $32^{\text {nd }}$ Hawaii International Conference on System Sciences, Hawaii, 4013: The potential impact of mega sport media on the travel decision-making process and destination choice- the case of Portugal and Euro 2004. Journal of Travel \& Tourism Marketing, 24(2-3), 127-137. doi:10.1080/10548400802092601

Seaton, A., \& Hay, B. (1998). The marketing of Scotland as a tourism destination, 1995-96. In R. MacLellan, and R. Smith (Eds.), Tourism in Scotland (pp. 209-240). London: International Thompson Business Press.

Square, S. (1994). The cultural values of literary tourism. Annals of Tourism Research, 21, 103-120.

Staggs, T. (2014, September 12). 'Frozen' attraction coming to Epcot. Disney Parks Blog. Retrieved September 13, 2014 from http://disneyparks.disney.go.com/blog/2014/09/frozen-attraction-coming-to-epcot/.

Su, H. J., Huang, Y. A., Brodowsky, G., \& Kim, H. J. (2011). The impact of product placement on TV induced tourism: Korean TV dramas and Taiwanese viewers. Tourism Management, 32(4), 805-814. doi:10.1016/j.tourman.2010.06.020

Succi, M. J. \& Walter, Z. D. (1999). Theory of user acceptance of information technologies: An examination of health care professionals.

The Walt Disney Company Q1 FY14 Earnings Conference Call. (2014, February). Retrieved August 3, 2014, from http://cdn.media.ir.thewaltdisneycompany.com/2014/q1/q1-fy14-earnings-transcript.pdf.

The Walt Disney Company. (2015, February). Quarterly earning reports. Retrieved February 16, 2015, from http://thewaltdisneycompany.com/investors/financial-information/earnings.

Thurston, S. (2014, May). 'Frozen' frenzy creates shortage for Elsa, Anna merchandise. Tampa Bay Times. Retrieved August 3, 2014, from http://www.tampabay.com/news/business/retail/frozen-frenzy-creates-shortage-for-elsa-annamerchandise/2180802.

Tooke, N. \& Baker, M. (1996). Seeing is believing: The effect of film on visitor numbers to screened locations. Tourism Management, 17(2), 87-94. doi:10.1016/0261-5177(95)00111-5

Williams, A. \& Palmer, A. (1999). Tourism destination brands and electronic commerce: Towards synergy. Journal of Vacation Marketing, 5, 263-275.

Zakarin, J. (2014, May). America's 'Frozen' Obsession Continues, Leading to Disney Store Lotteries and Disneyland Craziness. The Wrap: Covering Hollywood. Retrieved August 3, 2014, from http://www.thewrap.com/americas-frozenobsession-continues-leading-crazy-wait-times-disney-store-lotteries.

Zara, C. (2014). Disney animated sensation Frozen has created a bonanza for Norwegian tourism. Retrieved August 3, 2014, from http://www.independent.co.uk/arts-entertainment/films/features/disney-animated-sensation-frozen-has-created-abonanza-for-norwegian-tourism-9497045.html

Zhou, Z. (2002). Users' attitudes toward Web advertising: Effects of internet motivation and Internet ability. Advances in Consumer Research, 29, 71-78. 